\title{
Green vs Traditional Roofs: Assessing their Actual Benefits through an Integrated Indicator Developed for Cool Roofs
}

\author{
Maria La Gennusa ${ }^{1}$, Concettina Marino ${ }^{2}$, Antonino Nucara ${ }^{2}$, Giorgia Peri ${ }^{1}$, Gianfranco Rizzo ${ }^{1}$, \\ Gianluca Scaccianoce ${ }^{1,3}$ \\ ${ }^{1}$ Department of Engineering (DIING), University of Palermo, Italy \\ ${ }^{2}$ Department of Civil, Energy, Environmental and Material Engineering (DICEAM), \\ "Mediterranea" University of Reggio Calabria, Italy, \\ ${ }^{3}$ National Research Council of Italy, Institute of Biomedicine and Molecular Immunology, Palermo, \\ Italy
}

\begin{abstract}
Abstr act
Green roofs have caught on in cities, mainly because contribute positively to thermal behaviour of buildings equipped with them. This paper investigates the applicability to these roofs of an integrated indicator, developed by Levinson and Akbari, to assess the contribution of cool roofs to buildings' energy consumption. A building, assumed as the reference for the Italian medium size offices, was considered and its energy performance with and without the green roof was assessed. Different sites with different climatic conditions were considered for the simulations. First results indicate that such indicator does not seem to be completely transferable to green roofs.
\end{abstract}

\section{Introdu ction}

Energy behaviour of buildings is strongly affected by the features and configurations of the envelope structures (Milone et al., 2015; Mitja Košira et al., 2018). Therefore, if properly designed, they can contribute to minimize the overall energy demand of buildings, thus allowing the achievement of a high-energy performance, which is the basis of the recently introduced Nearly Zero Energy Building (NZEB) concept (Chiarisi, 2015; D’Agostino and Zangheri, 2016).

Among the new building components, green roofs are being used widely in urban contexts nowadays because, apart from the generally aesthetical benefits provided to buildings equipped with them, they have proved to deliver a positive contribution to the thermal behaviour of buildings (Ascione et al., 2013; Bevilacqua et al., 2016; Peri et al., 2016). Indeed, their effect on energy consumption of buildings has largely been investigated during recent years. Many studies indicate significant reductions of the annual building energy use obtainable using this kind of components, especially in the case of the installation on existing roofs characterized by a low level of insulation. Niachou et al. (2001), for instance, report a total energy saving achievable with green roofs ranged between $31 \%$ and $56 \%$ for non-insulated buildings, between $3 \%$ and $12 \%$ for moderately insulated buildings (a $5 \mathrm{~cm}$ layer of insulation), and between $2 \%$ and $3 \%$ for well insulated buildings (a $10 \mathrm{~cm}$ layer of insulation). Jaffal et al. (2012) indicate for an entire year an energy saving percentage varying from $3 \%$ (for buildings with a $30 \mathrm{~cm}$ layer of insulation) to $50 \%$ (for non-insulated buildings). Table 1 gives details of some of these green roof-related studies in which the impact of green roofs on the total energy demand (i.e. energy saving $\downarrow$ or increase $\uparrow$ ) compared to traditional roofs is presented.

In these studies, the contribution of green roofs to energy consumption for space heating and cooling is presented as well, also indicated in Table 1. Based on this literature review, it arises that there is a wide agreement among scientists on the fact that during the summer period the presence of green roofs provides a thermal protection for the building equipped with them, despite studies that show a negative impact of green roofs on cooling (Silva et al., 2016) are present.

The direct shading of the roof surfaces due to the presence of vegetation, the cooling effect of the ambient air due to the evapotranspiration process, and the increased albedo of the roof are recognized as the most important phenomena that enable this type of component to save energy in buildings, particularly in summer. Typical values for the albedo of green roofs vary, in fact, from 0.7 to 0.85 , which is much higher than albedo of a typical, $0.1 \div 0.2$, bitumen, tar, and gravel roofs (Saadatian et al., 2013).

On the contrary, the performance of vegetated roofs in winter is somewhat a controversial issue. As shown in Table 1, in fact, green roofs mostly reduce the total heating load but in some cases can result as without importance or even slightly adverse.

The additional insulation layer provided by the green compound added to the roof and the lower heat convection on the external surface caused by the presence of the vegetation, contribute to reducing the heat losses through the roof. Nonetheless, some circumstances may increase the heat losses, shortly indicated in the following. During sunny warm winter days, when ambient temperatures are higher than the indoor building temperatures, the presence of the green roof prevents the winter solar radiation to enter the envelope, resulting in a indoor temperature lower than that achievable without green roof (Sfiakianaki et al., 2009). In addition, the more wet the green roof substrate is, the higher its conductivity level is and therefore the corresponding heat losses. Sailor et al. (2008), for instance, experimentally measured thermal properties of ecoroof soil samples over a range of moisture states and indeed report thermal conductivity ranged from 0.25 to $0.34 \mathrm{~W} /(\mathrm{m} \mathrm{K})$ for dry samples and 
Table 1: Characteristics of some existing studies concerning the thermal contribution of green roofs (GR) ( $\downarrow$ reduction of energy consumption compared to trad itional roof; $\uparrow$ increase of energy demand compared to trad itional roof; $=$ ne utral impact).

\begin{tabular}{|c|c|c|c|c|c|}
\hline \multirow[t]{2}{*}{ Reference } & \multirow[t]{2}{*}{ City } & \multirow[t]{2}{*}{ Gr een roof ana lysed } & \multicolumn{2}{|c|}{$\begin{array}{l}\text { Impact of GR on the } \\
\text { seasonal energy need for }\end{array}$} & \multirow{2}{*}{$\begin{array}{l}\text { Impact of GR on } \\
\text { the tot al annual } \\
\text { energy demand }\end{array}$} \\
\hline & & & Heating & Cooling & \\
\hline \multirow{3}{*}{$\begin{array}{l}\text { Silva et al., } \\
2016\end{array}$} & \multirow[t]{3}{*}{ Lisbon } & Extensive GR & $\downarrow$ & $\uparrow$ & $\uparrow$ \\
\hline & & Semi-intensive GR & $\downarrow$ & $\downarrow$ & $\downarrow$ \\
\hline & & Intensive GR & $\downarrow$ & $\downarrow$ & $\downarrow$ \\
\hline \multirow{3}{*}{$\begin{array}{l}\text { Niachou et al., } \\
2001\end{array}$} & \multirow[t]{3}{*}{ Athens } & GR on non-insulated roof & $\downarrow$ & $\downarrow$ & $\downarrow$ \\
\hline & & GR on moderately insulated roof & $\downarrow$ & $\downarrow$ & $\downarrow$ \\
\hline & & GR on well insulated rood & $\downarrow$ & $\downarrow$ & $\downarrow$ \\
\hline \multirow{5}{*}{$\begin{array}{l}\text { Jaffal et al., } \\
2012\end{array}$} & Athens & GR in the Mediterranean climate & $\uparrow$ & $\downarrow$ & $\downarrow$ \\
\hline & La Rochelle & GR in the temperate climate & $=$ & $\downarrow$ & $\downarrow$ \\
\hline & Stockholm & GR in the cold climate & $\downarrow$ & $\downarrow$ & $\downarrow$ \\
\hline & \multirow[t]{2}{*}{ La Rochelle } & GR with insulation level $<10 \mathrm{~cm}$ & $\downarrow$ & $\downarrow$ & $\downarrow$ \\
\hline & & GR with $10 \mathrm{~cm} \leq$ insulation level $\leq 30 \mathrm{~cm}$ & $=$ or $\uparrow$ & $\downarrow$ & $\downarrow$ \\
\hline \multirow{2}{*}{$\begin{array}{l}\text { Santamouris } \\
\text { et al., } 2007\end{array}$} & \multirow[t]{2}{*}{ Athens } & GR on non-insulated roof & $\downarrow$ & $\downarrow$ & $\downarrow$ \\
\hline & & GR on insulated roof & $\uparrow$ & $\downarrow$ & $\downarrow$ \\
\hline
\end{tabular}

0.31 to $0.62 \mathrm{~W} /(\mathrm{m} \mathrm{K})$ for wet samples. In addition, the evapotranspiration process, typically occurring in these types of roofs, increases thermal losses. In fact, Lazzarin et al. (2005), for instance, have found in winter an outgoing thermal flux from the green roof $40 \%$ higher than the corresponding one of a high solar absorbing and insulated roofing. Evidently, water content and evapotranspiration are strictly related. Consequently, depending on which elements prevail, the impact of green roof on the total energy use for heating is different (i.e. a net energy saving or an increase). In literature, there are present also studies showing a monthly analysis of the energy performance of both the whole building and the top floor, with and without the green roof. Santamouris et al. (2007), for instance, report for non-insulated buildings monthly heating energy savings of $2 \div 3 \%$; and monthly heating energy increases up to $12 \%$. While, they report for the top floor of non-insulated buildings monthly heating energy savings of $3 \div 5 \%$ and monthly heating energy increases up to $26 \%$.

Clearly, higher energy savings may be achieved for the top floor, as shown in the study carried out by Santamouris et al. (2007). However, if deployed on a city scale, vegetated roofs have been demonstrated to provide a positive effect on the urban environment by reducing, thanks to the evapotranspiration effect, the ambient air temperatures. Santamouris (2014), for instance, by referring to the existing simulation studies, indicates for green roofs a possible reduction of the average ambient temperature ranged between 0.3 and $3 \mathrm{~K}$. Therefore, green roofs represent also an interesting technological option for mitigating the urban heat island (UHI) phenomena (Solcerova et al., 2017), which is one of the main environmental challenges of our time.

Based on the above-mentioned mostly positive impact of vegetated roofs on total energy consumption of buildings, and its consequent wide use in urban areas, an integrated indicator, by means of which likely assessing their energy performance, would be useful. Two researchers Levinson and Akbari (2010) have proposed a synthetic indicator for a simple evaluation of the energy performances of highalbedo roofs (also known as cool roofs). This indicator combines the benefits provided in summer by cool roofs (energy savings for cooling operations) with the disadvantages provided in winter (increases of the heating energy demand).

Hence, in this study we question whether this indicator might be used for green roofs as well, despite their previously cited sometime confusing behaviors.

To fulfil this goal, a reference building for the Italian medium size office edifices (Corgnati et al., 2013; Fabrizio et al., 2011) was considered and the EnergyPlus (U.S. Department of Energy, 2018) code was used for the energy simulations. This software implements the green roof model proposed by Sailor (2008), which is based on the FASST model developed by Frankenstein and Koenig (2004) for the US Army Corps of Engineers. Furthermore, the effect of diverse climate conditions were investigated, with a view to analysing when and where this indicator could be considered the best course of action.

\section{Method s and materials}

A simple method for the evaluation of the energ $y$ perf ormance of green ro ofs

Starting from the consideration that, when installing a cool roof on a building with electric cooling and natural gas heating, cooling energy savings and heating energy penalties will occur, Levinson and Akbari (2010) have developed a comparative and comprehensive indicator to quantify quickly the influence of a cool roof on the building's annual heat balance.

The indicator $1(\mathrm{x}, \mathrm{y})$, that is the dimensionless "load change" ratio, is expressed as the ratio of the increase of the annual heating energy (gas) use per CRA (the"conditioned roof area") - $\mathrm{g}(\mathrm{x}, \mathrm{y})$ [therm/area] - to the 
decrease of the annual cooling energy (electricity) use per CRA - e $(\mathrm{x}, \mathrm{y})[\mathrm{kWh} / \mathrm{area}]$ - , as follows:

$$
l(x, y)=\frac{\eta_{h}^{-1} \times g(x, y)}{e(x, y) \times E E R \times 0,01 \text { therm } / k B T U}
$$

where $\eta_{h}$ is the dimensionless efficiency of the heating equipment and EER (energy efficiency ratio) is the dimensional coefficient of performance of the cooling equipment $[\mathrm{BTU} /(\mathrm{h} \cdot \mathrm{W})], 1$ therm $=105.48 \mathrm{MJ}, 1 \mathrm{BTU}=$ $1054.349 \mathrm{~J}$.

According to the two researchers, the local reduction in annual cooling load, e $(\mathrm{x}, \mathrm{y})$, and the local increase in annual heating load, $g(x, y)$, when replacing a traditional roof with a more solar-reflective cool roof, are supposedly roughly proportional to expressions 2 and 3 respectively:

$$
\Delta \rho \times A \times R^{-1} \times \overline{\mathrm{I}}(x, y) \times C(x, y)
$$

and

$$
\Delta \rho \times A \times R^{-1} \times \overline{\mathrm{I}}(x, y) \times H(x, y)
$$

where:

$\Delta \rho$ is the increase in roof solar reflectance;

$\mathrm{A}$ is the roof area;

$\mathrm{R}$ is the thermal resistance of the roof assembly;

$\bar{I}(\mathrm{x}, \mathrm{y})$ is the local annual mean global horizontal solar irradiance;

$\mathrm{C}(\mathrm{x}, \mathrm{y})$ is the local number of annual cooling degree days; $\mathrm{H}(\mathrm{x}, \mathrm{y})$ is the local number of annual heating degree days; $(\mathrm{x}, \mathrm{y})$ locates the building in a projected (flat) Earth coordinate system.

Based on its definition, a value of this dimensionless synthetic indicator smaller than 1 means that heating energy penalties are smaller than cooling energy savings, while a value higher than 1 means that the increase in annual heating load prevails over the reduction in annual cooling load. Therefore, the first occurrence signals a convenience of adopting cool roofs.

In the following, after a brief description of the reference building and weather climatic conditions considered for the analysis, an application of the synthetic indicator proposed by Levinson and Akbari to green roofs is presented, in order of investigating the practicability of such indicator also for green roofs.

The analy sed office build ing and the modelled green roofs

The building here used as a model for the analyses is a reference building for Italian medium size office edifices (Corgnati et al., 2013; Fabrizio et al., 2011). It has a covered area of $2400 \mathrm{~m}^{2}$ and consists of five storeys of $480 \mathrm{~m}^{2}$ above the ground. The interior plan layout of the typical floor is structured around a central core (Figure 1), where stairs, elevators and service areas are located, whereas the border rooms are used as offices.

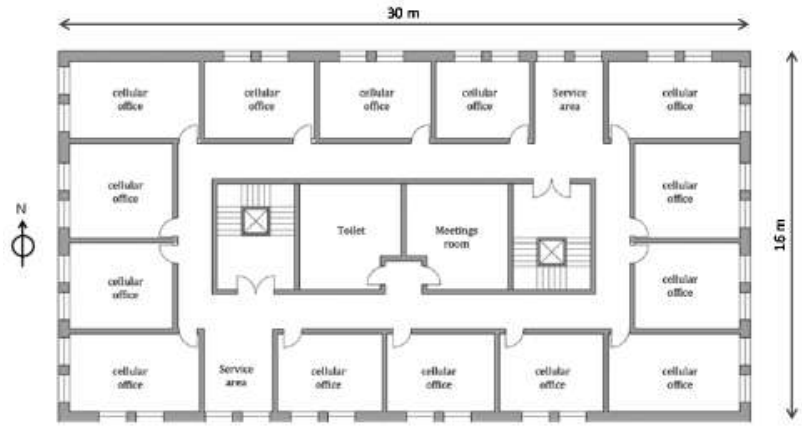

Figure 1: Plan view of the typical floor of the reference building.

Specifically, object of the analysis was the fifth storey (whose floor was assumed as adiabatic) of this building. This choice finds its basis on the fact that, as mentioned earlier, the effect of the energy performances of the roof, which are under investigation, mainly reverberates on the energy demand of the top floor, whereas inferior storeys are hardly affected. Figure 2 reports a sketch of the studied storey.

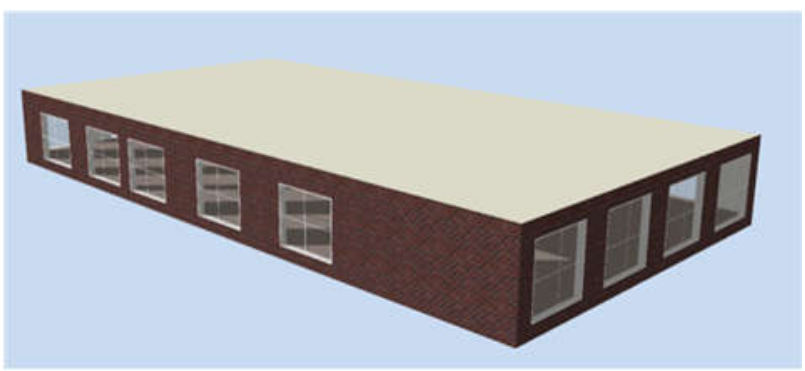

Figure 2: Sketch of the studied reference building's storey.

The thermo-physical properties of both the opaque envelope structures (external walls and roof) and the glazed surfaces are reported in Tables 2 and 3, respectively.

Table 2: Thermo-physical features of the opaque components of the envelope of the studied building.

\begin{tabular}{|c|c|c|c|}
\hline $\begin{array}{c}\text { Component } \\
\text { type }\end{array}$ & $\begin{array}{c}\text { Thickness } \\
(\mathrm{m})\end{array}$ & $\begin{array}{c}\text { Thermal } \\
\text { Tra nsmitt ance } \\
\left(\mathrm{W} / \mathrm{m}^{2 \circ} \mathrm{C}\right)^{\mathrm{b}}\end{array}$ & $\begin{array}{c}\text { Intern al } \\
\text { heat } \\
\text { capa city } \\
\left(\mathrm{kJ} / \mathrm{m}^{2}{ }^{\circ} \mathrm{C}\right)\end{array}$ \\
\hline Wall & $0.37^{\mathrm{a}}$ & 0.773 & 614 \\
\hline Flat roof & 0.30 & 0.851 & 359 \\
\hline
\end{tabular}

As regards the use of the building, indoor thermal comfort, occupancy, lighting, equipment, ventilation, and infiltration schedules were defined based on the study carried out by Corgnati et al. (2013) and the technical 
report carried out by Corgnati et al. (2012), assumed as representative of the daily usage of those buildings.

Table 3: Thermo-physical features of the transparent components of the envelope of the studied building

(EnergyPlus output).

\begin{tabular}{|c|c|}
\hline $\begin{array}{c}\text { Glass ther mal } \\
\text { tra nsmitta nce }\left(\mathrm{W} / \mathrm{m}^{2} \mathrm{~K}\right)\end{array}$ & $\begin{array}{c}\text { Solar heat gain coefficient } \\
\text { (SHGC) }(\text { dimensionless })\end{array}$ \\
\hline 3.146 & 0.713 \\
\hline
\end{tabular}

All the mentioned data are reported in Table 4.

Table 4: Features of systems and environment occupancy data in the studied building.

\begin{tabular}{|c|c|c|}
\hline & $\begin{array}{l}\text { Values adopted for } \\
\text { simulation s }\end{array}$ & Schedule \\
\hline \multirow{6}{*}{ People } & 0.06 & $9: 00-17: 00$ \\
\hline & Person $/ \mathrm{m}^{2}$ & Monday to Friday \\
\hline & \multirow{4}{*}{$\begin{array}{c}0 \\
\text { Person/m² }\end{array}$} & $17: 00-9: 00$ \\
\hline & & Monday to Friday \\
\hline & & $0: 00-24: 00$ \\
\hline & & Saturday and Sunday \\
\hline \multirow{6}{*}{ Lighting } & \multirow{2}{*}{$13 \mathrm{Wm}^{-2}$} & $9: 00-17: 00$ \\
\hline & & Monday to Friday \\
\hline & \multirow{4}{*}{$6.5 \mathrm{Wm}^{-2}$} & 17:00-9:00 \\
\hline & & Monday to Friday \\
\hline & & $0: 00-24: 00$ \\
\hline & & Saturday and Sunday \\
\hline \multirow{6}{*}{ Equipment } & \multirow{2}{*}{$10 \mathrm{Wm}^{-2}$} & $9: 00-17: 00$ \\
\hline & & Monday to Friday \\
\hline & \multirow{4}{*}{$0 \mathrm{Wm}^{-2}$} & $17: 00-9: 00$ \\
\hline & & Monday to Friday \\
\hline & & $0: 00-24: 00$ \\
\hline & & Saturday and Sunday \\
\hline \multirow{6}{*}{ Ventilation } & \multirow{2}{*}{$11 \mathrm{l} /$ person } & $9: 00-17: 00$ \\
\hline & & Monday to Friday \\
\hline & \multirow{4}{*}{$01 /$ person } & 17:00-9:00 \\
\hline & & Monday to Friday \\
\hline & & $0: 00-24: 00$ \\
\hline & & Saturday and Sunday \\
\hline Infiltration & $0.1 \mathrm{~m}^{3} \mathrm{~s}^{-1}$ & always \\
\hline
\end{tabular}

The primary systems, which allow both heating and cooling needs to be met, consist respectively of a gas boiler and an air cooled chiller; the terminals are four pipe fan coil units (Corgnati et al., 2013).

Table 5 lists the heating and cooling set points, along with pertinent schedules.
Table 5: System set points.

\begin{tabular}{|c|c|c|}
\hline & Set-point temper at ure $\left({ }^{\circ} \mathrm{C}\right)$ & Schedule \\
\hline \multirow{4}{*}{ Heating } & \multirow[b]{2}{*}{20} & $9: 00-17: 00$ \\
\hline & & $\begin{array}{l}\text { Monday to } \\
\text { Friday }\end{array}$ \\
\hline & \multirow[b]{2}{*}{15} & $17: 00-9: 00$ \\
\hline & & $\begin{array}{l}\text { Monday to } \\
\text { Friday }\end{array}$ \\
\hline \multirow[b]{2}{*}{ Cooling } & \multirow[b]{2}{*}{26} & $9: 00-17: 00$ \\
\hline & & $\begin{array}{c}\text { Monday to } \\
\text { Friday }\end{array}$ \\
\hline
\end{tabular}

Two different energy carriers feed the cooling and heating primary systems: electricity and natural gas.

On the other hand, the global energy consumption of the selected building was evaluated in terms of primary energy, using the following expression:

$$
E=f_{P E, n g} Q_{n g}+f_{P E, e} Q_{e}
$$

where:

$\mathrm{E}$ is the global primary energy consumption $(\mathrm{kWh})$;

$\mathrm{Q}_{\mathrm{ng}}$ is the energy delivered as natural gas, feeding the heating system $(\mathrm{kWh})$;

$f_{P E, n g}$ is the primary energy conversion factor for natural gas;

$\mathrm{Q}_{\mathrm{e}}$ is the energy delivered as electricity, feeding the cooling system $(\mathrm{kWh})$;

$f_{\mathrm{PE}, \mathrm{e}}$ is the primary energy conversion factor for electricity.

The values of the primary energy conversion factors, $f_{\mathrm{PE}, \mathrm{ng}}$ and $\mathrm{fE}_{\mathrm{PE}, \mathrm{e}}$, assumed in the present analysis (UNI/TS 113004:2016; Delibera EEN 3/08: 2008) are 1 and 2.174, respectively.

On the top of the reference building three roof options have been hypothesized and modelled here, that is: a cool roof (with a solar absorptance of 0.2 ), a green roof with low leaf area index (namely LAI $=1$ ) and plant height of $5 \mathrm{~cm}$, and a green roof with high LAI (namely LAI $=5$ ) and plant height of $20 \mathrm{~cm}$. Table 6 lists the features of the simulated green roof options.

As far the irrigation, a smart modality has been selected and an irrigation level of 0.002 meters of water per hour was ensured from $1^{\text {st }}$ October until $31^{\text {th }}$ May, while for the rest of time 0.004 meters of water per hour were hypothesized.

Results of the simulations, carried out using EnergyPlus software, were compared to the performances of a conventional roof. In the analysis, the structures of green roofs were arranged so that their thermal transmittance, referred to dry soil conditions, meets the thermal transmittance of the conventional roof. This choice finds its basis on the willingness to assess the behaviour of such different components under equal conditions. 
Table 6: Main features of the green roof options used to carry out the simulations.

\begin{tabular}{|l|c|}
\hline Gr een roofs' para meter s & Values \\
\hline Leaf Reflectivity & 0.4 \\
\hline Leaf Emissivity & 0.9 \\
\hline Minimum Stomatal Resistance (s/m) & 180 \\
\hline Roughness & Medium \\
\hline Soil thickness (m) & 0.1 \\
\hline Conductivity of Dry Soil $(\mathrm{W} / \mathrm{m}-\mathrm{K})$ & 0.35 \\
\hline Density of Dry Soil $\left(\mathrm{kg} / \mathrm{m}^{3}\right)$ & 561 \\
\hline Specific Heat of Dry Soil $(\mathrm{J} / \mathrm{kg}-\mathrm{K})$ & 1061 \\
\hline Thermal Absorptance & 0.9 \\
\hline Solar Absorptance & 0.8 \\
\hline Visible Absorptance & 0.6 \\
\hline $\begin{array}{l}\text { Saturation Volumetric Moisture Content of the } \\
\text { Soil Layer }\end{array}$ & 0.4 \\
\hline $\begin{array}{l}\text { Residual Volumetric Moisture Content of the Soil } \\
\text { Layer }\end{array}$ & 0.01 \\
\hline
\end{tabular}

The consider ed weather conditions

The analysis presented here has been extended to 65 main Italian sites. Very different climatic conditions characterize the territory of the Italian peninsula. In fact, according to the Köppen climate classification (Kottek et al., 2006), they span from a relatively cool mid-latitude version of the continental climate, Dfa, typical of inland northern areas of Italy, to a Mediterranean climate profile, Csa, typical of coastal and Southern areas. Parameters describing the climate conditions are Heating Degree Days and Cooling Degree Days (UNI 10349:2016; Federici et al., 2013; Terrinoni et al., 2012). Cities considered in the analysis (Figure 3) are characterized by HDD ranged approximately between 1000 and 3000, whereas CDD ranged between 0 and 120 .

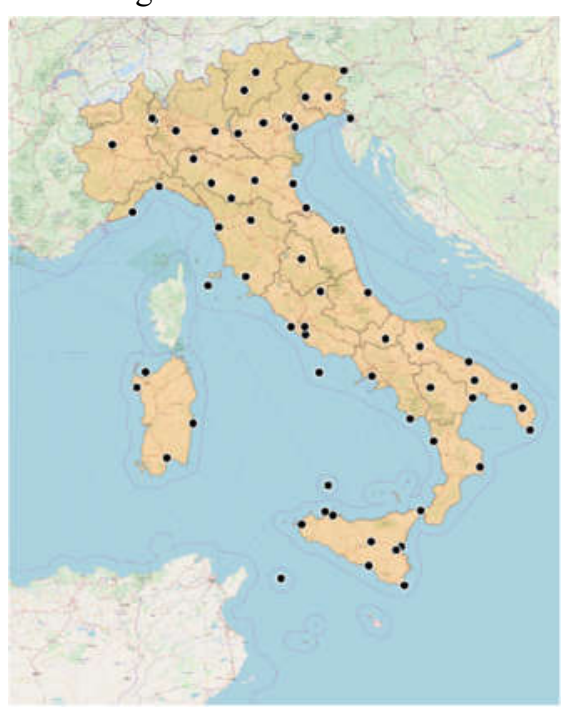

Figure 3: Maps of Italy with indications of the considered sites.

Here, sites selected to perform the simulations have climate conditions that are representative of this variety and, hence, allow a reliable appraisal of the effect of the weather variability on the energy efficiency of the building envelope.

Climatic data used to execute the simulations are those reported in the EnergyPlus database (U.S. Department of Energy, 2018).

\section{Results and Discussion}

Results of the simulations executed in the present study are shown in Figures 4 and 5. Specifically, graphs indicate for the analyzed four roofing options (standard roof, cool roof, green roof with low LAI, and green roof with high LAI) the variation of the building seasonal unitary primary energy demand (EP) of the case study with the HDD and the CDD for the analysed sites.

As shown in Figure 4, for each roof option, data correlate quite well in a second order polynomial regression indicating that an increase of HDD increases the heating energy need.

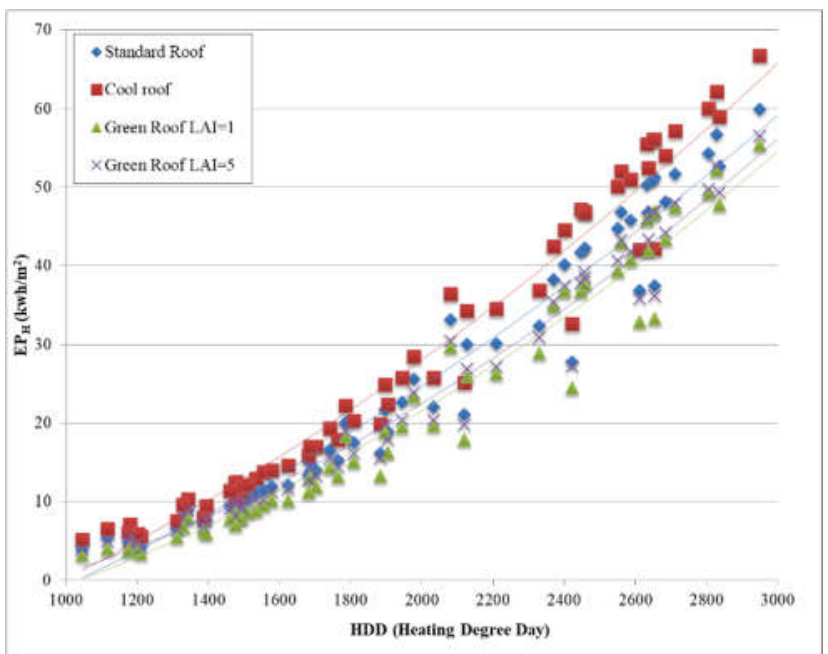

Figure 4: Comparison of the winter energy performance of the selected four roof options.

As for the energy performance of green roof and traditional roof solutions, Figure 4, which compares the energy use for each roof solution in the winter period, indicates that both green roof options (with LAI values equal to 1 and 5) reduce (but for few exceptions in the case of green roofs with $\mathrm{LAI}=5$ ) the heating energy need, when compared to the standard roof, in this way exhibiting a better performance than that of the standard roof. In other words, both options contribute to an energy saving for space heating compared to the traditional roof. The specific site location does not influence the results.

As regards the cooling season, as shown in Figure 5, for each roof option, data signal a general trend according to which an increase of CDD increases the cooling energy need. In addition, it has not to be overlooked that the link between cooling energy consumption and CDD is not so clear as that one between the heating energy consumption and HDD. 


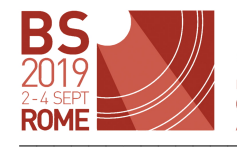

16th IBPSA

INTERNATIONAL
CONFERENCE

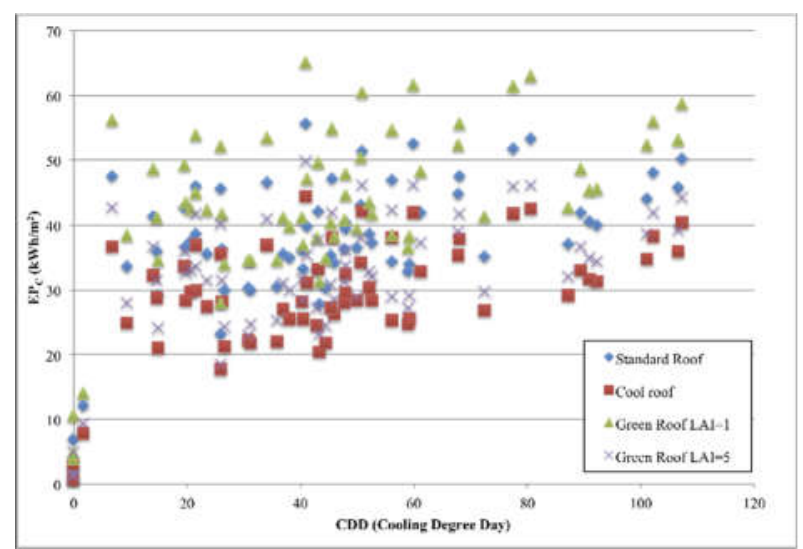

Figure 5: Comparison of the summer energy performance of the selected four roof options.

In summer, green roof options behave differently with respect to traditional roofs, based on the pertinent LAI value. Specifically, as it can be seen from Figure 5, only green roofs with high LAI (LAI $=5$ in these simulations) contribute to reduce the energy use for cooling, while green roofs with low LAI (LAI=1 in these simulations) increase the cooling energy demand compared to that of standard roof. This result is probably because the low level of foliage determines, on one hand, a relatively less cooling effect due to evapotranspiration and, on the other hand, a somewhat small shading effect of the roof surface. However, the outcomes of EnergyPlus seem to show that green roofs with low LAI are not able to release in nighttime the thermal energy accumulated during the diurnal period, despite at night the outdoor temperature, lower than the indoor one, should favour this heat loss.

Also in summer period, this behaviour does not seem to change with the specific site locations.

The circumstance of a negative effect of green roofs on cooling, that is among the outcomes of the present analysis, might appear quite surprising; however, such a result is confirmed by green roof studies present in literature that report a negative impact of extensive green roofs on energy uses for cooling too (Silva et al., 2016).

Anyway, as expected, cool roofs have resulted to be the most efficient option in summer, while the worst in winter. In addition, this behaviour is independent from the specific site location.

Figure 6 illustrates through coloured circles the different values assumed by the indicator in the case of adoption of cool roofs for different Italian cities. The colour of circles is correlated to the value of the indicator. In detail, green, yellow, and red circles refer to values of the indicator smaller than 0.75 , ranged between 0.75 and 1 , and higher than 1 , respectively.

As it can be observed from Figure 6, the South and almost all the costal zones are suitable to take advantage of benefits provided by cool roofs. Sites located along Alps and Apennine mounts do not seem to be quite suitable to cool roofs, while, North areas show a sort of borderline behaviour, signalling that the adoption of cool roofs is of controversial convenience.

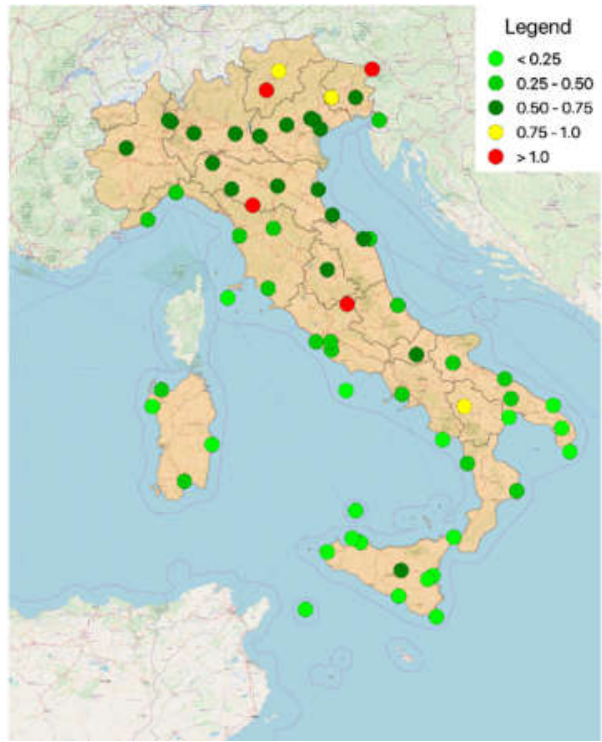

Figure 6: Classification of the considered sites based on the indicator proposed by Levinson and Akbari in the case of cool roofs.

Based on the outcomes of the present analysis, green roofs with low LAI show an opposite behaviour to that of cool roofs. They, in fact, unlike cool roofs, reduce the energy need for heating and increase that for cooling. Then, in this case, a value of the indicator smaller than 1 means that increases of cooling needs are higher that the reductions of heating needs, which in turn mean a net energy increase. In other words, while in the case of cool roofs a value of the indicator less than 1 indicates convenient conditions, in the case of green roofs (at least for those with low values of LAI) a value of the indicator less than one signals an unfavourable condition.

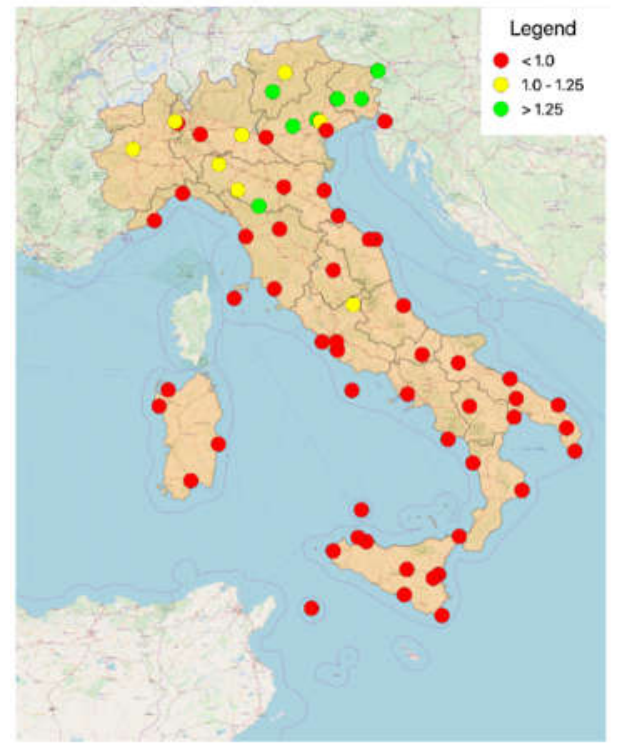

Figure 7: Classification of the considered sites based on the indicator proposed by Levinson and Akbari in the case of green roofs with low LAI 
Therefore, the previously described indicator might still be used for this type of green roofs but with the abovecited differences. Figure 7 confirms such an opposite behaviour, highlighting a major benefit for the sites in the North of Italy.

As for green roofs with high LAI values, a positive contribution is provided for both cooling and heating (but for few exceptions). In this case, therefore, the indicator does not give an indication about the energy convenience (as it does in the case of LAI $=1$ instead) of the green roof compared to a conventional roof, but it gives only an indication regarding the importance of the energy saving for heating compared to that of the energy saving for cooling. In other words, in these cases a value of the indicator less than 1 simply indicates that the reduction of the energy demand for cooling purposes is higher than that for heating purposes. As it can be seen from Figure 8, the smallest values of the indicator have been obtained for sites located in the South, while the highest for sites located in the North.

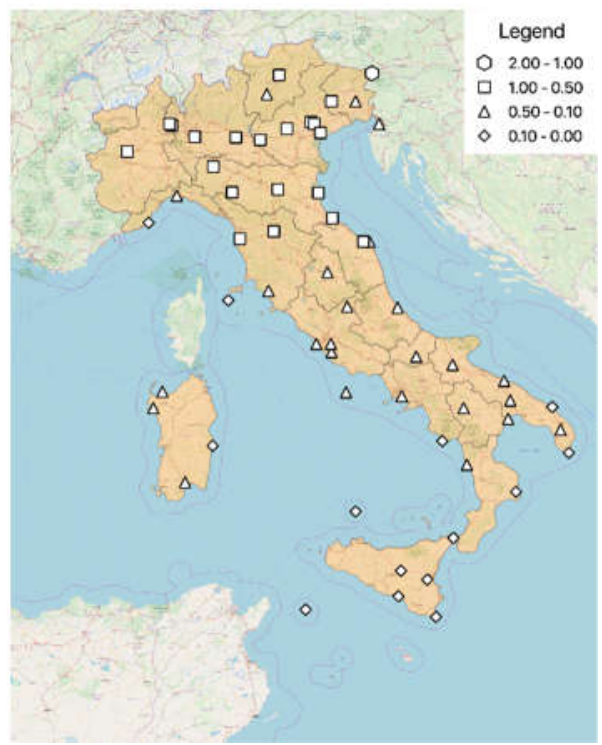

Figure 8: Classification of the considered sites based on the indicator proposed by Levinson and Akbari in the case of green roofs with high LAI

Therefore, in the case of green roofs with high LAI, this indicator does not seem to be directly applicable, at least until a benchmark value of convenience is set.

\section{Conclus ion}

The results presented here derive from an analysis extended to 65 localities in Italy, from North to South. First results of this study indicate that the indicator proposed for cool roofs does not seem to be applicable as it is also to green roofs, but for green roofs characterized by low LAI values, with the previously indicated differences. For high values of LAI, on the contrary, since the indicator only signals the relative benefits of heating to cooling reductions (both of them present in buildings equipped with such green compounds), it does not seem to be applicable as it is, unless a benchmark value of energy convenience is set.
Anyway, the indicator proposed for cool roofs maintains an effectiveness, particularly related to the fact that it provides a synthetic quantitative judgement about the applicability of a green roof by an energy point of view.

Besides, further analyses are needed, particularly concerning the relationship between types of the vegetated essences and their effects on the energy behaviour of buildings.

\section{Ackn owledgement}

This work was carried out within the research project $n$. 201594LT3F, "La ricerca per i PAES: una piattaforma per le municipalità partecipanti al Patto dei Sindaci (Research for SEAP: a platform for municipalities taking part in the Covenant of Mayors)", which is funded by the PRIN (Programmi di Ricerca Scientifica di Rilevante Interesse Nazionale) of the Italian Ministry of Education, University and Research.

\section{References}

Ascione, F., Bianco, N., de' Rossi, F., Turni, G. and G. P. Vanoli (2013). Green roofs in European climates. Are effective solutions for the energy savings in airconditioning? Applied Energy 104, 845-859.

Autorità per l'energia elettrica il gas ed il sistema idrico (2008). Delibera EEN 3/08 - Aggiornamento del fattore di conversione dei $\mathrm{kWh}$ in tonnellate equivalenti di petrolio connesso al meccanismo dei titoli di efficienza energetica. In: GURI n.100 29.04.2008 - SO N. 107, 2008. (in Italian)

Bevilacqua, P., Mazzeo, D., Bruno, R. and N. Arcuri (2016). Experimental investigation of the thermal performances of an extensive green roof in the Mediterranean area. Energy and Buildings 122, 63-69.

Corgnati, S.P., Fabrizio, E., Filippi, M. (2012). Reference Buildings for Cost-Optimal Analysis: the activities of the TEBE Research Group. In The European Portal For Energy Efficiency In Buildings (Build Up). Available

at: http://www.buildup.eu/en/practices/publications/refer ence-buildings-cost-optimal-analysis-activities-teberesearch-group.

Corgnati, S.P., Fabrizio, E., Filippi, M. and V. Monetti (2013). Reference buildings for cost optimal analysis: Method of definition and application. Applied Energy 102, 983-993.

Košira, M., Gostišab, T. and Ž. Kristlc (2018). Influence of architectural building envelope characteristics on energy performance in Central European climatic conditions. Journal of Building Engineering 15, 278288.

European Committee for Standardization (2007). Energy performance of buildings - Energy requirements for lighting (CEN, EN 15193).

Charisi, S. (2017) The role of the building envelope in achieving nearly-zero energy buildings (nZEBs). Pro cedia Environmental Sciences 38, 115-120. 
D’Agostino, D., Zangheri P. (2016) Development of the NZEBs Concept in Member States. Towards Nearly Zero Energy Buildings in Europe. In Publications Office of the European Union: Luxembourg.

Ente Nazionale Italiano di Unificazione (2016). Riscaldamento e raffrescamento degli edifici (norme della serie UNI 10349) (in Italian).

Ente Nazionale Italiano di Unificazione (2016). Energy performance of buildings. Part 4: Renowable energy and other generation systems for space heating and domestic hot water production (UNI/TS 11300-4).

Fabrizio, E., Guglielmino, D., \& Monetti, V. (2011). Italian benchmark building models: the office building. Proceedings from Build. Simul. 12th Conf. Int. Build. Perform. Simul. Assoc. Sydney (Australia), 2011.

Federici, A., Iatauro, D., Romeo, C., Signoretti, P., \& Terrinoni, L. (2013). Climatic Severity Index: definition of summer climatic zones in Italy through the assessment. Proceedings from Clima 2013 RHEVA Word Congr. Int. Conf. IAQVEC. Prague (Czech Republic), 2013.

Frankenstein, S., Koenig, G. (2004). FASST Vegetation Models, U.S. Army Engineer Research and Development Center, Cold Regions Research and Engineering Laboratory (ERDC/CRREL), Technical Report TR-04-25.

Kottek, M., Grieser, J., Beck, C., Rudolf, B. and F. Rubel (2006). World map of the Köppen-Geiger climate classification updated. Meteorologische Zeitschrift. 15, 259-263.

Lazzarin, R. M., Castellotti, F. and F. Busato (2005). Experimental measurements and numerical modelling of a green roof. Energy and Buildings 37, 1260-1267.

Levinson, R. and H. Akbari (2010). Potential benefits of cool roofs on commercial buildings: conserving energy, saving money, and reducing emission of greenhouse gases and air pollutants. Energy Efficiency 3, 53-109.

Jaffal, I., Ouldboukhitine, S.E. and R. Belarbi (2012). A comprehensive study of the impact of green roofs on building energy performance. Renewable Energy 43, 157-164.

Milone, D., Peri, G., Pitruzzella, S. and G. Rizzo (2015). Are the Best Available Technologies the only viable for energy interventions in historical buildings? Energy and Buildings 95, 39-46.

Niachou, A., Papakonstantinou, M., Santamouris, M., Tsangrassoulis, A. and G. Mihalakakou (2001). Analysis of the green rof thermal properties and investigation of its energy performance. Energy and Buildings 33, 719-729.
Peri, G., Rizzo, G., Scaccianoce, G., La Gennusa, M. and P. Jones (2016). Vegetation and soil - related parameters for computing solar radiation exchanges within green roofs: Are the available values adequate for an easy modeling of their thermal behavior? Energy and Buildings 129, 535-548.

Saadatian, O., Sopian, K., Salleh, E., Lim, C.H., Riffat, S., Saadatian, E., Toudeshki, A. and M.Y. Sulaiman (2013). A review of energy aspects of green roofs. Renewable and Sustainable Energy Reviews 23, 155 168.

Sailor, D.J. (2008). A green roof model for building energy simulation programs. Energy and Buildings 40, 1466-1478.

Sailor, D.J., Hutchinson, D. and L. Bokovoy (2008). Thermal property measurements for ecoroof soils common in the western U.S. Energy and Buildings 40(7), 1246-1251.

Santamouris, M., Pavlou, C., Doukas, P., Mihalakakou, G., Synnefa, A., Hatzibiros, A. and P. Patargias (2007). Investigating and analysing the energy and environmental performance of an experimental green roof system installed in a nursery school building in Athens, Greece. Energy 32(9), 1781-1788.

Santamouris, M. (2014). Cooling the cities - a review of reflective and green roof mitigation technologies to fight heat island and improve comfort in urban environments. Solar Energy 103, 682-703.

Sfakianaki, A., Pagalou, E., Pavlou, K., Santamouris, M. and M. N. Assimakopoulos (2009). Theoretical and experimental analysis of the thermal behaviour of a green roof system installed in two residential buildings in Athens, Greece. International Journal of Energy Research 33, 1059-1069.

Silva, C. M., GlÂria Gomes, M. and M. Silva (2016). Green roofs energy performance in Mediterranean climate. Energy and Buildings 116, 318-325.

Solcerova, A., van de Ven, F., Wang, M., Rijsdijk, M. and N. van de Giesen (2017). Do green roofs cool the air? Building and Environment 111, 249-255.

Terrinoni, L., Signoretti, P., Iatauro D. (2012). Indice di severità climatica : classificazione dei comuni italiani ai fini della climatizzazione estiva degli edifici, 2012. Available at: http://www.enea.it/it/Ricerca sviluppo/documenti/ric erca-di-sistema-elettrico/risparmio-energia-settorecivile/2011/107-rds-pdf.

U.S. Department of Energy (2018). EnergyPlus ${ }^{\mathrm{TM}}$ Version 9.0.1 Documentation, Input Output Reference. 